\title{
Aspects of the parasitism of edible mussel, Perna perna (Linnaeus, 1758) (Bivalvia, mytilidae), from the Guanabara Bay, Rio de Janeiro, Brazil
}

\author{
Rhanieri Siqueira, ${ }^{*}$ Eliana de Fátima Marques de Mesquita, ${ }^{*}$ Francisco Carlos de Lima, ${ }^{\text {* }}$ \\ Robert Barber** \& Ana Paula Martins de Souza*
}

Guanabara Bay is located in the heart of Rio de Janeiro City $\left(22^{\circ} 54^{\prime} \mathrm{S}, 43^{\circ} 15^{\prime} \mathrm{W}\right)$ and an estuarine region for several rivers and canals of high-level density areas of populations and industries. As a matter of fact the Bay has been used as a place to release waste of different sources. The degradation of this environment has been responsible for the negative effects on the fishing areas. L.P.H. Oliveira \& L Krau (1976, Mem. Inst. Oswaldo Cruz, 3 (2-4) : 435-449, Rio de Janeiro) have referred that pollution in Guanabara Bay has been known as a problem for the future since 1930 .

High level sedimentation shows the great evidence of anthropogenic action, which is responsible for ecological changings, increasing of degradation or disappearance of animal's populations. A natural geological deposit was around $19 \mathrm{~cm}$ per 100 years. Between 1849 and 1922 it was around $24 \mathrm{~cm}$ and between 1938 and $1962,81 \mathrm{~cm}$ (E.S. Amador, 1980, An. Acad. Bras. Cien., 52 : 723- 742, Rio de Janeiro).

Although mussel populations are not documented as having experienced the number and severity of mass mortalities recorded for various oyster species, there are several records citing major die-offs of cultured and wild populations (Korringa, 1951, Rev. Trav. Off. (Scient. Tech.) Pech. Marit. 17 (2) : 2-13; Li et al., 1979; J. Invert. Pathol., 33 : 108110, Munford et al. 1981; J. World Mar. Soc., 12 (2) :186199, Figueras et al. 1991; J. Shellfish Res., 10 (1) : 89-94.

H. Marques \& R. Pereira (1988, Boletim Técnico n¹2, 32p., Instituto de Pesca, São Paulo) reported some aspects of the biology and cultivation of mussels on São Paulo State, Brazil refering to some parasites problems. Recently A.R.M.Magalhães (1998, Tese de Doutorado - IBUSP, São Paulo) investigated the effect of bucephalid trematode on the reproduction, biochemical composition and condition index of mussels from the coast of Santa Catarina State.

Between later 1997 and 1998, we initiated a survey sites on Guanabara Bay coast where Perna perna (Linnaeus, 1758), a Brazilian edible mussel, is distributed through out rocky areas and a total of 500 mussels were picked up in shallow subtidal populations at Guanabara Bay, RJ. Samples of 10 or 15 animals from four sites (Curvo, Flexas (Itapuca Stone), Boa Viagem Beaches and Naval Island) were collected once a month (Table). The sizes of the animals on shells ranged from $4.7 \mathrm{~cm}$ to $5.6 \mathrm{~cm}$ in total length and from. $2.1-\mathrm{cm}$ to $2.6 \mathrm{~cm}$ in total width. Those animals were processed immediately after removal from the water. They were fixed without being shucked in Bouin's fixative for at least 4 hours and transferred to $10 \%$ formalin for 24 hours. A narrow opening was cut in their shells to permit the penetration of fixative solution deeply in the tissues.

Transverse tissue sections including digestive gland, mantle, gills, gonad and foot were obtained from the total body. After fixing, the tissues were embedded in paraffin, sectioned at $5 \mathrm{~mm}$ in cross section, and stained with Harris hematoxylin and eosin. Microscopic analysis was carried out at low and high dry magnifications, as well as under oil immersion.

The sites for this research were designed to describe regional distributions of contamination and four of them were selected for monitoring generally 10 to 50 kilometers $(\mathrm{km})$ apart. There is increasing evidence that environmental stress and man-made water pollution in particular may lead to debilitation and disease in numerous marine animals including bivalves.

A gregarinian-like protozoan, similar to Nematopsis ostrearum Prytherch, 1940, was found in the samples collected in January '98 at Curvo, Boa Viagem Beaches and Naval Island sites. Some of these protozoan were found in samples of February '98 at Naval Island, Boa Viagem Beach and Itapuca Stone. Two species of Nematopsis, i.e., $N$. ostrearum and $N$. prytherchi, infect $C$. virginica along the Atlantic and Gulf coasts of the United States (V. Sprague, 1949, J. Parasitol., 35 : 42, V. Sprague \& P.E. Orr Jr., 1955, J. Parasitol., 41 : 89-104). S.Y. Feng (1958, Proc. Natl. Shellfish. Assoc., $48: 162-173$ ) demonstrated that N.ostrearum spores are phagocytosed by hemocytes, distributed in various oyster tissues, and gradually eliminated from the tissues.

\footnotetext{
*Universidade Federal Fluminense, Departamento de Tecnologia de Alimentos, Rua Dr. Vital Brazil Filho n. 64, Niterói, Rio de Janeiro, Brasil. Fax: +55-21-714-4041. Email: mpvefmm@vm.uff.br

${ }^{\star \star}$ Rutgers, The State University of New Jersey, Haskin Shellfish Research Laboratory, 6959 Miller Avenue, Port Norris, New Jersey, USA. Email: bob@vertigo.hsrl.rutgers.edu
} 
Trematodes of the genus Bucephalus are well known parasites of fresh water and marine bivalves and fish. Sporocysts develop in digestive and reproductive tissues, often causing parasitic castration (T.C. Cheng, 1967, Adv. Mar. Biol. 5 : 1-424); C.J. Sindermann (1970, Principal Diseases of Marine Fish and Shellfish, 369pp.) and C.J. Sinderman (1990, Principal Diseases of Marine Fish and Shellfish, v.2, Diseases of Marine Shellfish, 516pp.). B. haimeanus and $B$. cuculus are flat worm parasites of European flat oysters and American oysters. Only one specimen from Naval Island collected in early December ' 97 showed bucephalid trematode, Bucephalussp, in gonad. It was impossible to identify the sex of the animal as the gonad was completely destroyed by the parasite. Late January '98 two animals from Boa Viagem Beach and one from Naval Island presented the gonad parasite. This parasite spread out all over gonad and adductor muscle area in one specimen from Boa Viagem Beach and the sex was unable to be identified at this point.

A large cestode (Metacestode) showing a sort of encapsulation and host response was detected in the samples collected in January ' 98 at Naval Island and Boa Viagem Beach, and in February '98 at this last location again. A.K. Sparks (1963, J. Insect. Pathol. 5: 284-288) and T.C. Cheng (1966, Trans. Amer. Microsc. Soc. 85 : 246-255) have reported a metacestode from the American oyster, C. virginica, from Hawaii. The occurrence of metacestodes of the lecanicephaloid cestode Tylocephalum was reported for the first time in the clam Tapes semidecussata from Hawaii by T.C. Cheng \& E. Rifkin (1968, J. Invert. Pathol., 10 : 65-69, 7figs).

One animal collected in January on Boa Viagem Beach appeared to show heavy inflammation and focal necrosis (tightly concentrated hemocyte aggregations) in the area of the gut and elsewhere. It sounds there is no apparent cause, but appears similar to cases where bacteria or a Vibrio is the cause (Robert Barber, personal communication). Some ciliated protozoan could be seen in the gut in this organism only.

Guanabara Bay at Rio de Janeiro State needs further investigation to point out economic bivalve diseases that may impact the local economy due to bad sanitary conditions and to improve environmental monitoring methodologies.

This is an intensive histological evaluation of a significant number of mussels collected from four sites. However, these initial findings will be of use to future larger-scale sampling programs, as the project will be continuing for two-year period.

Keywords: Edible Brazilian mussel; histopathology; parasitism; Perna perna; polluted areas.

Table: Guanabara Bay - Date, location and numbers of animals collected for this research.

\begin{tabular}{|c|c|c|c|c|c|c|c|c|c|c|c|c|c|c|}
\hline PLACE & & DEC & JAN & FEB & MAR & APR & MAI & JUN & JUL & AUG & SEP & $\mathrm{OCT}$ & NOV & DEC \\
\hline GEM BEACH & $\begin{array}{l}1997 \\
1998 \\
\end{array}$ & $x$ & 15 & 10 & 10 & 10 & 10 & $X$ & 10 & 10 & 10 & 10 & 10 & 10 \\
\hline $\mathrm{BEACH}$ & $\begin{array}{l}1997 \\
1998 \\
\end{array}$ & $X$ & 15 & 10 & 10 & 10 & 10 & $\mathrm{X}$ & 10 & 10 & 10 & 10 & 10 & 10 \\
\hline SLAND ("CARDOS") & $\begin{array}{l}1997 \\
1998 \\
\end{array}$ & 10 & 15 & 10 & 10 & 10 & $\mathrm{X}$ & $\mathrm{X}$ & 10 & 10 & $\mathrm{X}$ & 10 & 10 & 10 \\
\hline
\end{tabular}

$X:$ no samplings in May, June and September due to dangerous weather conditions.

Acknowledgements: to Carlos Eduardo Moreira Villas Bôas ("Cadú") for technical assistance and all co-workers and participants.

This work has been receiving support from Conselho Nacional de Desenvolvimento Científico e Tecnológico (CNPq) Processo n. 520419/98-7. 